\title{
Friend or Foe?: Bernard Williams and Political Constitutionalism
}

\author{
Cormac S Mac Amhlaigh ${ }^{1}$
}

Accepted: 9 September 2020 / Published online: 30 September 2020

(c) The Author(s) 2020

\begin{abstract}
This article looks at Bernard Williams's relevance to particular debates in constitutional theory about the legitimacy of two competing models of institutional design: political constitutionalism which endorses giving the final say on the meaning of constitutional rights to legislatures; and legal constitutionalism which endorses giving the final say on the meaning of rights to courts. Recent defences of political constitutionalism have made claims about the realism of their accounts when compared with legal constitutionalism and have co-opted Bernard Williams's realism to support their case. This article examines these claims, concluding that these accounts of political constitutionalism rely on a distinctly non-Williamsian form of political moralism in that they assume a legitimacy for political constitutionalism which is prior to politics and political disagreement. It offers an alternative defence of political constitutionalism, a partial defence, which, it argues, is closer to the realism of Bernard Williams than these accounts.
\end{abstract}

Keywords Political realism $\neq \cdot$ Liberalism $\cdot$ Legislative supremacy $\cdot$ Judicial supremacy $\cdot$ Judicial review $\cdot$ Fundamental rights protection

\section{Introduction}

Political Constitutionalism ('PC') is a form of what Waldron has called 'political' political theory (Waldron 2013). That is, that it is a form of political theory which relates specifically to the institutions of authority and their organisation in terms of their make-up, powers and relationships inter se. As such it can be distinguished from studies of institutions based on efficiency or consequences which have more traditionally been the concern of political science, or questions of justice which have traditionally been the concern of political theory and political philosophy (Waldron

Cormac S Mac Amhlaigh

cormac.mac.amhlaigh@ed.ac.uk

1 Edinburgh Law School, The University of Edinburgh, Old College, South Bridge,

Edinburgh EH8 9YL, UK 
2013, p. 10). Rather, as political theory, it attempts to create a link between more conventional political theory such as accounts of justice, liberty or equality, and forms of institutional design.

PC puts a particular emphasis on political disagreement involving not just the good, but also the right. It can therefore be distinguished as a theory of rights from liberal accounts which take the view that disagreements about rights are soluble by recourse to an 'original position' (Rawls 1973), 'overlapping consensus' (Rawls 1993) or according to a particular constitutional settlement (Dworkin 1978). PC's opening premise, then, is the 'fact' of disagreement about particular constitutional values which it then overlays with normative values of equality or equal respect and concern (Waldron 1999; Bellamy 2007).

PC is therefore political in two senses: it is political in that it attempts to provide a political theory of institutional design by tracing the relationship between the form and powers of institutions of authority and normative values, as well as emphasising the need for politics given societal disagreement on questions of normative values including fundamental rights. Adding together the fact of political disagreement with a need for institutions of authority which must act notwithstanding such disagreement, ${ }^{1}$ PC endorses the supremacy of democratically elected legislatures over courts as the most legitimate form of ultimate decision-making in democratic constitutional systems (Waldron 2006). It is this focus on a 'fact' of societal disagreement which have led some to characterise PC as a form 'realist' political theory, (Bellamy 2016; Fabbrizi 2018) and explains the recent adoption by political constitutionalists of the realist thinking of Bernard Williams to support their defence of legislative supremacy. $^{2}$

This contribution will explore the affinities between Williams's political realism and PC as an account of legitimate institutional design. It will examine the realist claims made by PC, as well as survey some recent attempts to support the PC position with Bernard Williams's realism. ${ }^{3}$ It argues that whereas there are some superficial affinities between the focus of PC and Williams's realist theory, ultimately Williams's account of legitimacy is not a natural ally of the PC position on questions of institutional design. This is due to the fact that in prescribing legislative supremacy as the most legitimate form of institutional design, PC, at least in the form endorsed by Waldron and Bellamy, constitutes a form of political moralism; an approach to legitimacy from which Williams explicitly attempted to distance himself in his realist account. Rather, the paper argues, Williamsian realism is more supportive of positions in the PC debate which argue that the legitimacy of PC is defensible, but only in part, where its legitimacy is predicated on the broader 'minimal legitimacy' of a governing regime (Mac Amhlaigh 2016a, b).

\footnotetext{
${ }^{1}$ What Waldron calls the 'circumstances of politics' defined as the 'felt need among the members of a certain group for a common framework or decision or course of action on some matter, even in the face of disagreement about what that framework, decision or action should be' (Waldron 1999, p. 102).

${ }^{2}$ In particular, his late essay 'Realism and Moralism in Political Theory' (Williams 2005). See (Waldron 2013; Bellamy 2016).

${ }^{3}$ With a particular emphasis on Bellamy (2016).
} 
The paper will proceed as follows: Part 2 provides a summary of Bernard Williams's well-known realist account of political legitimacy. Part 3 gives an overview of the PC position and particularly the links drawn by PC between political disagreement and the putative superior legitimacy of legislative supremacy. Part 4 traces the relationships drawn by political constitutionalists' defence of legislative supremacy and Williams's realist account of legitimacy. Part 5 shows that first impressions notwithstanding, PC, at least as defended by some of its main supporters, is better understood as a form of political moralism of the type that Williams rejected. Part 6 argues that Williamsian realism can support PC, but only with respect to partial defences of PC, where it features as part of the overall legitimacy of the governing regime.

\section{Bernard Williams's Political Realism}

Normative political theory is currently experiencing a 'realist turn' with a resurgence of interest in the realistic or non-ideal dimensions of normative theory (Galston 2010; Rossi and Sleat 2014). Much of the realist turn involves an attempt to shift the interests of political theory from questions of justice to questions of legitimacy and can therefore be interpreted, at least in part, as a backlash to the success of justicebased accounts of political theory such as that of John Rawls (Rossi and Sleat 2014). Within this realist turn in normative political theory, Bernard Williams's work on realism - and in particular his late essay 'Realism and Moralism in Political theory'-has proven to be particularly influential (Sleat 2010).

In the essay, Williams argues that conventional normative theories of politics such as liberalism or utilitarianism are forms of political moralism which start from the wrong place in thinking about the legitimacy of authority. The legitimacy of authority, starts, for Williams, not with the identification of utilitarian principles which provide a single teleology for political processes, ('the enactment model' of political moralism) or through the identification of a liberal moral framework within which politics can take place, ('the structural model' of political moralism), but with a response to what he calls the 'first political question'; that is the securing of 'order, protection, safety, trust, and the conditions of cooperation' (Williams 2005, p. 3).

For Williams, the first political question does not relate to a question which is first answered and settled before moving on to consider other political questions. Rather the first political question is 'first' in the sense that it is the paramount question of politics which is repeatedly asked and answered. This emphasis on the ongoing resolution of the first political question is one of the prominent realist features of Williams's account in describing how the legitimacy of authority actually works in practice. In this way, Williams's approach can be distinguished from liberal responses which tend to emphasise a relatively static, fixed political settlement which supports the legitimacy of subsequent political action.

Whereas the first political question is, for Williams, a necessary condition for the legitimacy of authority, it is not a sufficient condition. Politics must, moreover, satisfy a 'basic legitimation demand' ('BLD') (Williams 2005, p. 4). This requires the resolution of the first political question - the securing of order etc.-in an 
'acceptable' way. That is, alongside resolving the first political question, an authority must also offer a 'justification of its power' (Williams 2005, p. 5) to each subject. Williams is careful to distinguish politics from war or pure coercion, noting that 'the situation of one lot of people terrorizing another lot of people is not per se a political situation' (Williams 2005, p. 5). As much is clear, for Williams, from the premise of the first political question-if politics starts with the resolution of the first political question, then it is primarily concerned with a resolution of the violence and pure coercion which is conventionally associated with the idea of a state of nature. In asserting authority over its subjects, an authority makes a claim to the effect that its actions are an improvement over the state of nature, and as such it must demonstrate how its acts are, in fact, an improvement on this state of affairs.

As such, Williams's view is not one which is completely devoid of moral considerations. ${ }^{4}$ He notes, however, that the morality implicit in his starting point in the first political question is not a morality that is 'prior to politics' (Williams 2005, p. 5). It is, rather, a moralised conception of politics, at least to the extent that the safety and security of individuals is secured, and its securing is justified to each individual subjected to the authority. In this way, Williams's realism can be distinguished from classical realism which views politics as a method of getting power and holding on to it. ${ }^{5}$

One of the primary differences between Williams's account and liberal accounts of legitimacy, then, is that non-liberal states could be legitimate under Williams's account. For Williams, the under-specification of what, precisely, the BLD requires in terms of values and principles, means that liberalism goes further, sometimes much further, in terms of what the BLD requires. In Williams's view, liberals 'raise the standards' of what it means to fear insecurity, pain and suffering and 'raise the expectations of what the state can do' (Williams 2005, p. 7).

\section{Political Constitutionalism as Political Theory}

The realist elements in Williams's account of legitimacy have attracted the attention of political constitutionalists who see in him a natural ally to their accounts of legitimate institutional design. Their preference for legislative supremacy in questions of institutional design stems from a key empirical assumption they make about political life: disagreement. In advocating legislative supremacy, political constitutionalists depart from the 'circumstances of politics' (Waldron 1999, 102). In the circumstances of politics, not only do we disagree about the meaning of the good, but we also disagree about the right, including the origins, nature and meaning of fundamental rights as well as the values which they purport to protect. However, we still require collective action on these matters (Christiano 2000, p. 518). Thus, notwithstanding such disagreement, some decision-making authority is necessary to

\footnotetext{
${ }^{4}$ Leading some to argue that Williams is insufficiently 'realist' on this point (Sleat 2010).

5 Such as, for example, Machiavelli. See (Viroli 2018). For some this marks Williams out as a 'weak realist' (Rossi and Sleat 2014, p. 690).
} 
resolve the disagreement about the right and the good. Political constitutionalists, moreover, argue that we also need a decision-making procedure which is worthy of the respect of those over whom decisions are made; that is a decision-making authority which is legitimate. For political constitutionalists, the most legitimate form of decision-making authority is one which makes decisions according to a procedure which is respectful of all citizens involved in disagreement by treating them equally, that is where they are 'regarded as equals and their multifarious rights and interests accorded equal respect and concern' (Bellamy 2007, p. 5). Whereas they draw on different political theories in order to give content to their understandings of the equality and liberty of individuals in the circumstances of politics, ${ }^{6}$ they conclude that in questions of institutional design, and particularly the choice between judicial or legislative supremacy with regard to decision-making in the circumstances of politics, the latter form best respects their premises of equality in the face of disagreement, and is therefore the most legitimate form of institutional design (Waldron 2006).

\section{Bernard Williams and Political Constitutionalism}

With their common focus on the empirical realities within which political values are negotiated and applied in practice, the affinities between PC and Williams's account of political legitimacy are easy to see. In particular, the primary realist features of Williams's account — that political authority is something that needs to be negotiated on an ongoing basis, and that liberalism is not, in practice, the only way of securing political legitimacy-have a strong affinity with PC's emphasis on disagreement in fact about the meaning (and in particular the liberal meaning) of fundamental rights and their subsequent preference for legislative supremacy.

These affinities between Williamsian realism and PC have been teased out more explicitly recently by Richard Bellamy. ${ }^{7}$ In a recent reply to critics, he explicitly employs Williams's political realism to support the case for PC. Bellamy clarifies that the realism of PC lies not in its (ultimate) preference for legislative supremacy, but rather in its 'realist' starting point. This 'realist' starting point is the disagreement inherent the circumstances of politics; disagreement about 'which moral ends and modes of moral reasoning are to be preferred' (Bellamy 2016, p. 213). In this defence, Bellamy argues that Williams advances a conception of legitimacy that, like PC, establishes criteria for legitimate decision-making which are distinct from purely moral considerations.

He explicitly draws out the analogies between the political constitutionalists' emphasis on disagreement, and Williams's argument that political legitimacy begins

\footnotetext{
${ }^{6}$ For example, Waldron departs from a position of liberal equality, Bellamy from a republican conception of freedom as non-domination (Waldron 1999; Bellamy 2007). For a recent defence of legal constitutionalism on republican grounds, see (Hickey 2019).

${ }^{7}$ In particular (Bellamy 2016). Williams also gets a mention, albeit en passant, in Waldron's recent work (Waldron 2013, p. 7). See also (Fabbrizi 2018).
} 
with the ongoing answering of the 'first political question', concluding that both positions argue that "politics goes "all the way down", (Bellamy 2016, p. 207). ${ }^{8} \mathrm{He}$ argues that Williams's recognition that the BLD may not be answered in a singular stable way, shows that Williams acknowledges 'the disagreements and conflicts that stand behind the very need for politics' (Bellamy 2016, p. 212) which accords with the political constitutionalists' emphasis on the circumstances of politics and the resultant preference for legislative procedures to channel those disagreements.

Furthermore, for Bellamy, PC's emphasis on the 'priority of politics and the inescapability of procedures' (Bellamy 2016, p. 208) (due to the fact that an objective 'truth' about justice or legitimacy is elusive), overlaps with Williams's view that the BLD cannot be about a morality which is 'prior to politics' but is 'inherent to there being such a thing as politics' (Williams 2005, p. 5). He argues that Williams's position supports the PC view that the acceptability of an authority's response to the first political question stems from 'how rather than to what moral purpose or on what moral basis' (Bellamy 2016, p. 213) the power of the authority is exercised. Williams's view supports, Bellamy contends, the PC idea that the legitimacy of authority will depend on whether political power is exercised 'in a way that acknowledges the "circumstances of politics" which constitutes a manner capable of being perceived as "acceptable" by those subject to it' (Bellamy 2016, p. 213). This, for Bellamy, supports the idea that legitimacy is always necessarily about procedures and forums for articulating and justifying political positions, of which legislatures are the most conducive in questions of institutional design.

\section{Friend or Foe?: Bernard Williams and PC}

Whereas there are obvious affinities between PC and Williams's approach to political legitimacy, these are arguably more superficial than substantive. To see how Williamsian realism is potentially incompatible with PC we need to return to PC's 'realist' opening gambit; the circumstances of politics. In the circumstances of politics, we should not only expect disagreement about the good-what public policy should be pursued —or about rights-does freedom of expression protect hate speech?, does the right to privacy permit abortion?-but also whether legislative supremacy as endorsed by PC, is, in fact the fairest or most legitimate way to resolve these disagreements about rights. Whereas PC emphasises the first two forms of agreement, they neglect this third form of disagreement and it is this neglect which, it is argued, causes PC to pursue a path of political moralism in defending legislative supremacy making Williams a problematic ally to their cause.

More specifically, with regard to disagreement about whether legislative supremacy is the fairest method of resolving disagreements about rights in the circumstances of politics, PC attempts to resolve this disagreement in a way which fails to take seriously the good faith disagreement about the very question of whether

\footnotetext{
8 Williams does not explicitly make this link. He argues that the perpetual nature of the first political question lies in the fact that it is 'affected by historical circumstance' (Williams 2005, p. 3).
} 
legislative supremacy is the most fair or legitimate way to resolve disagreements about rights. Waldron, for example, argues that even if we disagree about secondorder procedures about whether judicial or legislative supremacy is the most legitimate way of resolving disputes about rights, we have no choice but to consider them. He argues that there are important reasons relating to legitimacy such as 'fairness, voice [and] participation' (Waldron 2006, p. 1372) which tip the balance in favour of majority rule in a legislative assembly to make decisions in the face of disagreement about whether legislative supremacy is, itself, the most legitimate way of resolving disagreement on this point. With regard to this second-order disagreement Waldron claims that we are left in a 'legitimacy free zone' where it is best to hope that a legitimate democratic system emerges 'somehow or other' (Waldron 1999, p. 300) For Bellamy, with respect to the second order disagreement about the most legitimate form of institutional design, he argues that we must simply grasp the 'procedural nettle' and start somewhere, whether that is the 'already existing political system' or in the case of new regimes, with whatever can be 'cobbled together' to get the regime-building ball rolling (Bellamy 2007, p. 174). Once something has got off the ground, however, Bellamy warns against constitutionalising these initial procedures as there will be disagreements about those selfsame procedures. The procedures must, therefore, be left open because we are constantly 'building the ship at sea' (Bellamy 2007, p. 174). He asserts that legislative decision-making is a 'neutral' (Bellamy 2016, p. 211) way of resolving disagreements on this second order question and that an ability to contest decision-making on an equal footing carries normative weight of an 'independent kind'. That weight consists in 'the way those subject to political decisions feel they are regarded within the decision-making process itself' (Bellamy 2016, p. 213). As such, he concludes that 'the only way to realize justice in our relations with others is through public deliberation about justice in which each has an equal say', and, that it becomes difficult for justice to be done in 'any other way' than by showing that it has been done 'through the equal involvement of those concerned' which is best achieved through legislative procedures. ${ }^{9}$

The problem with these responses to disagreement about the fairness of legislative supremacy is that they seem to constitute a form of non-Williamsian political moralism. As noted, for Williams, political moralism is a position which makes the 'moral prior to the political' (Williams 2005, p. 5), from which political disagreement can be approached and resolved. However, Waldron's and Bellamy's proposals to resolve the second order-disagreement about whether legislative supremacy or majority rule is, in fact, the most legitimate procedure for resolving first order disagreements about rights, involves an institutional arrangement which seems to be underpinned by a morality which is 'prior to', or 'outside of' disagreement under the circumstances of politics. This is apparent in their claims that legislative

\footnotetext{
9 Bellamy (2016, p. 214) (emphasis added). He supports this point by reference to Mill's comments on the 'morality of being listened to': ‘. . . it is a personal injustice to withhold from any one ... the ordinary privilege of having his voice reckoned in the disposal of affairs in which he has the same interest as other people' and 'everyone is degraded.. When other people ... take upon themselves unlimited power to regulate his destiny.. Everyone has a right to feel insulted by being a nobody, and stamped as of no account' (Mill 1998, p. 335).
} 
supremacy or majority rule as a way of resolving political disagreements about whether it is the most legitimate way of resolving disagreements is neutral, when it in fact represents a particular (contested) viewpoint from within the debate itself. ${ }^{10}$ The claims that 'fairness, voice [and] participation' have a special weight in the legitimacy of decision-making; or that legislative supremacy is 'the' theory of legitimacy (Waldron 2006, p. 1387); or that democracy is 'self-constituting' (Bellamy 2007 , p. 141) or retains an authority and legitimacy that is 'independent from the right or wrongness of the policies it is employed to decide' (Bellamy 2007, p. 141); or that 'the only way to realize justice in our relations with others is through public deliberation about justice in which each has an equal say' (Bellamy, 2016 p. 214); or that it becomes difficult to do justice in 'any other way' than by showing that it has been done 'through the equal involvement of those concerned' (Bellamy 2016, p. 214) are all precisely the type of claims about which we should expect disagreement in the circumstances of politics. To claim that they are 'neutral' or enjoy a superior legitimacy appears to claim a moral position for these views which is prior to, or transcends, political disagreement. In this sense, then, PC as defended by Bellamy and Waldron looks very like a form of political moralism. As a form of political moralism, it involves an 'applied morality' (Williams 2005, p. 2) presupposing moral clarity about the justice, or fairness or legitimacy of legislative supremacy which should shape our decisions about questions of institutional design; something which Williams was sceptical of.

In this sense, then, both Waldron's and Bellamy's defences of PC can be said to reflect the two types of political moralism identified by Williams. Waldron's account looks like a form of the 'structural model' of political moralism. The claim that legislative supremacy constitutes 'the theory of legitimacy' suggests that the only legitimate form of decision-making is one which conforms with the claims of PC as to the superior legitimacy of legislative supremacy and majority rule. On this view politics can only be legitimate when it takes place within the structures of a legislative supremacy model of institutional design which is a claim analogous to other liberal 'structural models'. Bellamy's account, on the other hand, resembles more closely the 'enactment model' of political moralism, whereby the aim of politics is to enact certain (a priori or transcendental) moral principles. This is clear in his emphasis that we must take institutional arrangements as we find them, but then work towards 'enacting' a model of legislative supremacy which becomes the ultimate moral telos of politics. ${ }^{11}$ However, it was precisely these ways of thinking about legitimacy from which Williams was attempting to distance himself in stipulating the first political question and the BLD as a more realist approach to the legitimacy of authority.

In associating PC with either the structural or enactment models of political moralism, we do not have to conclude that legislative supremacy is in some way

\footnotetext{
${ }_{10}$ Eisgruber (2002, p. 37). In a Razian sense, they fail as theories of authority in that the solution replicates the very disagreement which the authority is called upon to resolve. See (Mac Amhlaigh 2016a, p. 189).

11 That is, that the only telos of constitutionalism in Bellamy's account, is to keep the avenues and channels of disagreement open in the form of legislative supremacy as we are constantly building the ship at sea (Bellamy 2007, p. 173).
} 
inherently immoral or illegitimate. Williams nowhere states that political moralism is, itself, incompatible with the BLD. Political moralism does not, as such, represent a failure to answer the first political question in an 'acceptable' way; it is just one historically contingent answer to it. Rather, PC, like liberalism, 'raises the standards' as to what legitimacy_or the BLD—requires (Williams 2005, p. 13). In endorsing PC, as 'the' theory of legitimacy or 'the only way to realize justice in our relations with others', it, like liberalism, overshoots in what is required to satisfy the BLD. Thus, the political moralist mistake is to assume that no authority can be legitimate until the prescriptions of their theory are met, whereas Williams, departing from the premise of the solution to the first political question, argues that there are many ways in which an authority can be legitimate without meeting the (more exacting) standards of whatever account of moral theory the political moralist endorses-in our case, the superior morality of legislative decision-making. The first political question and the BLD, therefore could be answered according to a range of moral alternatives, including, potentially, legal constitutionalism.

Whatever the rights and wrongs of political moralism and PC as a form of political moralism as characterised here, what is clear is that in failing to the take the second-order disagreement about the legitimacy of legislative supremacy seriously, PC does not seem to be a particularly realist political theory in a Williamsian sense. ${ }^{12}$

\footnotetext{
12 There is one way in which Bellamy's defence of PC could, potentially, be rescued from the charge of political moralism which he needs to avoid for his claims regarding the political realism of PC to be plausible. He argues that the support of the 'input' features of political disagreement which are achieved through legislative supremacy aim at 'avoiding any group being so radically disadvantaged in putting its view that it could be regarded as being dominated by some other group or groups within that political society' (Bellamy 2016, p. 213). The use of Williams's terminology 'radical disadvantage' is interesting here. Williams contends that the BLD is not satisfied - that the answer to the first political question is not 'acceptable' - where a group subject to an authority is 'radically disadvantaged' (Williams 2005, p. 5). Being radically disadvantaged is defined as being disadvantaged as to what one can fear. For these purposes, 'what one can fear' is defined as 'what someone would reasonably be afraid of if it were likely to happen to him/her in the basic Hobbesian terms of coercion, pain, torture, humiliation, suffering, death'. Imposing such conditions on the response to the first political question does not result in political moralism as, as noted above, resolving such a situation through organised authority is part of what politics is about on Williams's view. Any response to the first political question which results in such outcomes fails to answer the first political question in that it fails to distinguish between politics and coercion. Therefore, if Bellamy's account is to avoid the charge of political moralism he needs to do more to show how judicial review of the democratic will of the legislature constitutes being radically disadvantaged in this sense. However, it seems a stretch to argue that having a piece of legislation produced by a democratically elected body overruled by an unelected, but procedurally constrained, reactive body which is generally appointed by elected representatives such as a constitutional court, could be classified as being 'radically disadvantaged' in terms of experiencing a form of coercion or humiliation. Furthermore, and more significantly, this does not seem to be what Williams had in mind in his definition of 'radical disadvantage'. As noted above, Williams nowhere states that political moralism is itself incompatible with the BLD such that practices of judicial review endorsed by liberals such as Dworkin is not a failure to answer the first political question in an 'acceptable' way; it is just one historically contingent answer to it (Williams 2005 p. 12). Liberalism (and potentially also judicial review) could simply be said to add more than what might be strictly necessary in order to answer the demand.
} 


\section{A Partial Defence of PC}

There is a position in PC debates which, it is submitted, can support PC, including as a method of resolving second-order disagreements about whether legislative supremacy is the fairest or most legitimate way of resolving first-order disagreements about the good and the right, in a way which is more conducive to a Williamsian realism than the putatively politically moralist defences put forward by Waldron and Bellamy. This position does not fully defend either legal or judicial supremacy on abstract normative grounds, but argues that both political and legal constitutionalism can be defended as legitimate arrangements in contexts in what it calls the goals of a minimal theory of legitimacy are realised. ${ }^{13}$ However the defence introduces an important qualifier: it will only be capable of defending PC where it is occurrent in actual practice. It is, in this sense, therefore, only a partial defence of political constitutionalism; it will also serve to defend legal constitutionalism in contexts where it is already practised and the requirements of the minimal theory of legitimacy are fulfilled. However, it is argued that this partial defence of PC is a more convincing defence of political constitutionalism in the Williamsian realist sense than, the 'full' defence of PC endorsed by Bellamy and Waldron.

The normative thrust of the partial defence of political constitutionalism is based on two ideas. Firstly, if we think of legal or political constitutionalism as normative theories-modes of practical reasoning prescribing reasons for action-then they are subject to constraints set by the 'moral costs of transition' (Räikkä 1998). That is, that in making particular prescriptions for action-such as institutional change from legal to political constitutionalism for example-a normative theory should factor in the moral costs in such change. ${ }^{14}$ Secondly, any normative theory prescribing reasons for action must make 'viable recommendations' in the sense that they must make recommendations which are both achievable and desirable ${ }^{15}$ (Stemplowska 2008, p. 324). Where the desirability of the prescriptions of a particular normative theory are in doubt because, for example, they are subject to good faith disagreement, then the viable recommendation condition of a normative theory is not met. In summary, the partial defence argues that, whereas the first condition can, in principle, be fulfilled by political constitutionalism as argued for particularly by Bellamy (although this will depend on the particular context), the second condition cannot in the light of disagreement about the most legitimate institutional arrangements in the circumstances of politics.

The partial defence of political constitutionalism invokes a minimal theory of legitimacy based on what Rawls called the 'Hobbes' thesis; that is the securing to an acceptable degree of the 'goods of the political' such as security and welfare by an authority (Michelman 2003). Where the Hobbes thesis applies to a given context, that is where an authority in practice reasonably successfully achieves the 'goods of

\footnotetext{
${ }^{13}$ For a fuller account of the minimal theory of legitimacy and its role in supporting a partial defence of PC see (Mac Amhlaigh 2016a, b).

14 What are often called 'feasibility constraints'.

15 On the requirements of normative theory more generally see (Mac Amhlaigh 2019).
} 
the political', then it can be said to be 'self-legitimating' under the minimal theory, to the extent that it does not transgress baseline moral principles (Raz 2009, p. 349). These principles determine the limits of the authority and self-legitimacy of actual constitutions or governing structures. In assessing the extent to which an authority secures the goods of the political, the minimal theory of legitimacy appraises an authority in the round as a 'governing totality', rather than looking at individual provisions, practices or laws applied by the authority. Thus, in assessing the legitimacy of an authority from the perspective of the minimal theory, we must look at the 'entire aggregate of concrete political and legal institutions, practices, laws, and legal interpretations currently in force' within the jurisdiction of the authority (Michelman 2003). Under the minimal theory, such an authority does not have to secure the goods of the political perfectly or, more importantly, perfectly justly (not least according to a liberal account of justice), provided that it does so reasonably well and in a reasonably fair and just way. As such the minimal theory takes jurisdictions as it finds them and examines the ways in which they can enjoy a baseline or minimum level of legitimacy through securing the goods of the political. In this way, the minimal theory defines 'a threshold above which legal regimes are sufficiently just to deserve the support of those who are subject to them in the absence of better, realistically attainable alternatives' (Fallon 2005, p. 1798). This thought is nicely captured by Copp through the metaphor of a 'leaky boat': it is better to be at sea in a leaky boat than have no boat at all (Copp 1999).

The legitimacy enjoyed by an authority which reasonably effectively secures the goods of the political creates a moral presumption in favour of the legitimacy of that authority under the minimal theory. As an authority only enjoys a presumption as to its legitimacy, the premises and arrangements upon which the goods of the political are secured by an authority in the minimal theory are merely 'pro tanto' reasons and are therefore defeasible. There is, the option in minimal theories to 'mutiny' should the 'captain of the ship' be incompetent or unjust ${ }^{16}$ (Copp 1999).

Thus, an important aspect of the minimal theory is the specification of the point at which an actual authority transgresses the threshold conditions such that it loses its legitimacy and individuals are no longer under a moral obligation to obey its commands. One easy, if abstract, case of when the reasons for submitting to authority are defeated is that envisaged by Copp; that is where societal needs 'are so poorly served by [an authority] that either the society would do better if people viewed themselves as under no moral duty at all to obey the law' (Copp 1999, p. 43) However, beyond this it is difficult to specify the exact point at which minimal theories are dislodged by countervailing moral considerations. One area where it is unlikely that the presumption in favour of the status quo will be dislodged is with respect to debates surrounding political and legal constitutionalism. That is, that the question of the legitimacy of legislative or judicial supremacy will by itself be insufficient to dislodge the presumption in favour of the legitimacy of a regime which secures the goods of the political in a reasonably fair and just way in the light of

\footnotetext{
${ }^{16}$ In this respect, the partial defence is not a form of what Estlund calls 'complacent realism'; that is, that which we are doing is also what we should be doing normatively speaking (Estlund 2014, p. 115).
} 
the disagreement about the legitimacy of each arrangement in the abstract (Mac Amhlaigh 2016b).

The partial defence, therefore, serves to support political constitutionalism where it is practiced and the minimal theory of legitimacy can be said to apply. Moreover, it does so in a way which takes second-order disagreements about legitimate procedures for resolving first-order disagreements about values seriously. In addressing the question of the legitimacy of authority within the confines of the debate on political and legal constitutionalism, the partial defence takes its constitutional settlements as it finds them and serves to support the legitimacy of whichever arrangement in terms of legislative or judicial supremacy is in place, provided that the goods of the political are secured in a reasonably just and fair way in the 'governing totality'. Significantly, this includes the use of extant procedures to resolve secondorder disagreement about the legitimacy of using those procedures.

Where such a totality involves PC, then the partial defence creates a moral presumption in favour of the legitimacy of PC, including its use to resolve these second-order disagreements. Where citizens disagree with PC in such a settlement, including its use to determine whether PC is the fairest way to resolve this secondorder disagreement, they can contest the use of PC. However, in doing so, they must advance compelling countervailing arguments for a judicial resolution of disagreements, including second-order disagreements about procedures. Given that such arguments will be competing with the 'self-legitimating' existing arrangements and the feasibility constraints of transition (based on the fact that they secure the goods of the political in reasonably just and fair way), they must show that their proposals will resolve disagreement about this second-order disagreement in a fairer way than the status quo, while simultaneously securing the goods of the political at an acceptable moral cost. If we assume the level of disagreement under the 'circumstances of politics', this will be a difficult, if not impossible task. ${ }^{17}$ In a context in which a governing arrangement involving legislative supremacy demonstrably secures the goods of the political in a reasonably just and reasonably fair way, arguments advanced by legal constitutionalism such as nemo iudex in causa sua, or that legal process is a more impartial way of determining such questions, or that judicial processes are better at emphasising potential injustices in governing arrangements (Waldron 2006, pp. 1395-1401) will suffer from two deficiencies. Firstly, they will not enjoy the 'self-legitimacy' attached to the existing governing arrangement practising legislative supremacy due to the potential feasibility constraints affecting such change ${ }^{18}$; and secondly, they will, themselves, be the subject of good faith disagreement and will therefore not be able to claim an independent superior legitimacy to legislative supremacy. Rather, the securing of the goods of the political in a reasonably fair

\footnotetext{
17 This is not to suggest that there may not be other reasons for constitutional change such as strategic political advantage or for reputational reasons. See (Ginsburg 2008). The point is that assuming disagreement in the circumstances of politics, the superior legitimacy of legal constitutionalism over political constitutionalism in the abstract, cannot be one of them.

18 Of course the extent to which feasibility constraints will feature as reasons against change will depend on the particular extant institutional arrangement. There may be cases where they will be low and therefore not operate as strong reasons supporting the status quo.
} 
way will be determinative of the issue - a legitimacy which covers the use of legislative supremacy to resolve such debates in this context. From the perspective of the partial defence, then, the normative weight of legislative supremacy where it is practised is contingent, yet, importantly, it supports the use of legislative supremacy to determine whether legislative supremacy is the most just or fair procedure for resolving first order disagreement where it exists and where the goods of the political are secured.

\section{The Partial Defence and Williams's Realism}

There are a number of features of this partial defence which make it more sympathetic to a Williamsian realism than the accounts of PC outlined above. Firstly, the starting assumptions of both theories are strikingly similar. The presumptions of the partial defence involving the securing of the goods of the political have a strong affinity with Williams's answering of the first political question and the relatively open-ended conditions of fulfilling the BLD. Secondly, and more importantly, the partial defence takes disagreement, including disagreement about the legitimacy of political constitutionalism, seriously, but in a way which does not assume a form of political moralism. The contingency in the support for PC in the partial defence based on the fact that it relies on facts external to the theory itself-that a version of PC is already part of a regime's institutional arrangements-means that it explicitly acknowledges that other forms of institutional design are also legitimate. In this way it is analogous to Williams's view that the conditions for fulfilling the BLD can be secured through a variety of different ways. ${ }^{19}$ In this way it eschews a moral position prior to politics with respect to the most legitimate form of decision-making in the circumstances of politics in a similar way to Williams's conception of the BLD. If the partial defence does stipulate a form of morality through the securing of the goods of the political, then it is a form of 'moralised' politics similar to the account put forward by Williams. Like the BLD, it does not assume a morality which is 'prior to politics' but rather, like the BLD, its morality is 'inherent in there being such a thing as politics'; hence the goods of the political upon which it is predicated (Michelman 2003). The partial defence is, like the BLD, incompatible with 'one lot of people terrorizing another lot of people', presupposing as it does, a minimal and acceptable level of safety and security which form part of the very goods of the political (Williams 2005).

In considering the legitimacy of particular governing arrangements, then, and particularly when considering the institutional arrangements of political or legal constitutionalism, both the partial defence and Williams's realism encourage usall other things being equal-to acknowledge the legitimacy of the institutional arrangements of a particular authority 'here and now' (Williams 2005, p. 11), and

\footnotetext{
19 Reducing the possibilities to the alternatives between judicial and legislative supremacy, the minimal theory accepts that such arrangements are the product of our historical 'circumstances' or 'conditions' and can enjoy a legitimacy notwithstanding the fact that they do not fulfil the prescriptions of a particular political moralist paradigm such as liberalism, or, indeed, PC (Williams 2005, p. 7).
} 
even to resolve disagreements about the legitimacy of those very arrangements. Moreover, in taking seriously disagreement about the legitimacy of legal or political constitutionalism in a context where legislative supremacy is used, and endorsing the use of legislative supremacy to resolve those disagreements, the partial defence, in Williamsian fashion, encourages us to view our convictions about PC (or legal constitutionalism), not as 'simply autonomous products of moral reason' but rather as 'another product of historical conditions ${ }^{20}$ In this way, the legitimacy of PC will be based on the historical contingency of its existence in fact in a particular governing arrangement.

As such, then, given that the partial defence accepts its constitutional arrangements as it finds them within a broader securing of the goods of the political, where legislative supremacy is practised in a particular context, it will be considered appropriate 'now and around here' Williams $(2005$, p. 8) as a way of resolving disagreements, including disagreements about whether legislative supremacy is the fairest way to resolve such disagreements. Its central normative commitments will " "make sense" as authoritative to those subject to them' (Rossi and Sleat 2014, p. 693). As Williams notes, this is a 'sound application' of a 'general truth', the truth discovered by Goethe's Faust: Im Anfang war die Tat-in the beginning was the deed (Williams 2005, p. 14).

\section{Conclusion}

Debates in constitutional theory such as those regarding the legitimacy of legislative or judicial supremacy in the interpretation of fundamental rights, have not been immune to the broader 'realist turn' in normative political theory. However, in emphasising the idea of disagreement as a central realist feature of such theories, it is important that we are realist 'all the way down' as it were, and also embrace the disagreements which will affect the conclusions of PC; that legislative supremacy is necessarily the fairest or most legitimate way of resolving disagreements about rights. This article endorsed a partial defence of PC in order to achieve these aims. It argued that it does a better job of taking seriously second-order disagreement about the fairest way of resolving disagreement about the interpretation of fundamental rights than conventional accounts of PC. Moreover, it is also closer to a Williamsian realist position than those accounts, notwithstanding their co-option of Williams to their particular defences. That the partial defence is just that-only partial-is, it is submitted, a necessary price to

\footnotetext{
${ }^{20}$ Williams $(2005,13)$. Indeed, there is evidence in Williams's essay that this is precisely what he, himself, thought about the legitimacy of particular constitutional arrangements such as legislative or judicial supremacy. Towards the end of the essay, he notes that ' $[\mathrm{t}]$ here are needs that people have which seemingly can be met only by more directly participatory structures; but equally, there are objectives which are notoriously frustrated by these, and other aims which are at least in competition with them, and considerations which raise doubts about the extent to which any procedures can be really participatory anyway. No transcendental or partly transcendental argument-one might say more generally, theoretical argument-could serve to resolve these conflicts' (Williams 2005, p. 16). Emphasis Added.
} 
pay to secure the realism of PC as an account of a legitimate theory of authority which takes disagreement seriously and factors historical context into an account of legitimacy in Williamsian fashion. At least with respect to the bare choice between legislative or judicial supremacy, in the absence of an Archimedean point from which to resolve such disagreement, we fall back on the historical 'deeds' of past practice to secure the authority of constitutional arrangements. Thus, whereas Williams can be considered to be a 'friend' of PC, it is only with respect to partial defences of the theory.

\section{Funding}

Open Access This article is licensed under a Creative Commons Attribution 4.0 International License, which permits use, sharing, adaptation, distribution and reproduction in any medium or format, as long as you give appropriate credit to the original author(s) and the source, provide a link to the Creative Commons licence, and indicate if changes were made. The images or other third party material in this article are included in the article's Creative Commons licence, unless indicated otherwise in a credit line to the material. If material is not included in the article's Creative Commons licence and your intended use is not permitted by statutory regulation or exceeds the permitted use, you will need to obtain permission directly from the copyright holder. To view a copy of this licence, visit http://creativecommons.org/licen ses/by/4.0/.

\section{References}

Bellamy, R. 2007. Political Constitutionalism. Cambridge: Cambridge University Press.

Bellamy, R. 2016. Turtles All the Way Down? Is the Political Constitutionalist Appeal to Disagreement Self-defeating? A Reply to Cormac Mac Amhlaigh. International Journal of Constitutional Law 14(1): 204-216.

Christiano, T. 2000. Waldron on Law and Disagreement. Law and Philosophy 19: 513-543.

Copp, D. 1999. The Idea of a Legitimate State. Philosophy \& Public Affairs 28(1): 3-45.

Dworkin, R. 1978. Taking Rights Seriously. London: Duckworth.

Eisgruber, C. L. 2002. Democracy and Disagreement: A Comment on Jeremy Waldron's Law and Disagreement. New York University Journal of Legislation and Public Policy 6: 35-47.

Estlund, D. 2014. Utopohobia. Philosophy \& Public Affairs 42(2): 113-134.

Fabbrizi, V. 2018. Normativism and Realism within Contemporary Democratic Constitutionalism. Philosophy and Social Criticism 44(6): 661-681.

Fallon, R. 2005. Legitimacy and the Constitution. Harvard Law Review 118(6): 1787-1853.

Galston, W. 2010. Realism in Political Theory. European Journal of Political Theory 9(4): 385-411.

Ginsburg, T. 2008. The Global Spread of Constitutional Review. In The Oxford Handbook of Law and Politics, ed. G. Caldeira, R.D. Keleman, and K.E. Whittington, 81-95. Oxford: Oxford University Press.

Hickey, T. 2019. The Republican Core of the Case for Judicial Review. International Journal of Constitutional Law 17(1): 288-316.

Mac Amhlaigh, C. 2016a. Putting Political Constitutionalism in its Place. International Journal of Constitutional Law 14(1): 175-197.

Mac Amhlaigh, C. 2016b. Clinging to my Turtle: A Rejoinder to Adrienne Stone and Richard Bellamy. International Journal of Constitutional Law 14(1): 217-219.

Mac Amhlaigh, C. 2019. Who's Afraid of Suprastate Constitution Theory?: Two Reasons to be Sceptical of the Sceptics. In Legitimacy: The State and Beyond, ed. W. Sadurski, M. Sevel, and K. Walton, 182-205. Oxford: Oxford University Press.

Michelman, F. 2003. Ida's Way: Constructing the Respect-Worthy Governmental System. Fordham Law Review 72: 345-365.

Mill, J. 1998. On Liberty and Other Essays. Oxford: Oxford University Press. 
Räikkä, J. 1998. The Feasibility Condition in Political Theory. The Journal of Political Philosophy 6(1): 27-40.

Rawls, J. 1973. A Theory of Justice. Cambridge, MA: Harvard University Press.

Rawls, J. 1993. Political Liberalism. New York: Columbia University Press.

Raz, J. 2009. Between Authority and Interpretation. Oxford: Oxford University Press.

Rossi, E., and Matt Sleat. 2014. Realism in Normative Political Theory. Philosophy Compass 9(10): 689-701.

Sleat, M. 2010. Bernard Williams and the Possibility of a Realist Political Theory. European Journal of Political Theory 9(4): 485-503.

Stemplowska, S. 2008. What's Ideal About Ideal Theory? Social Theory and Practice 34(3): 319-340.

Viroli, M. 2018. Realism and Prophecy in Machiavelli and in Italian Political Culture. The Italianist 37(3): 308-323.

Waldron, J. 1999. Law and Disagreement. Oxford: Oxford University Press.

Waldron, J. 2006. The Core of the Case Against Judicial Review. Yale Law Journal 115: 1346.

Waldron, J. 2013. Political Political Theory. The Journal of Political Philosophy 21(1): 1-23.

Williams, B. 2005. Realism and Moralism in Political Theory. In In the Beginning Was the Deed, ed. G. Hawthorn, 1-17. Princeton, NJ: Princeton University Press.

Publisher's Note Springer Nature remains neutral with regard to jurisdictional claims in published maps and institutional affiliations. 